\title{
ECONOMIC MANAGEMENT MODEL OF ELECTRICITY GENERATED FROM BIOMASS IN A PIG FARM
}

\author{
Patrícia Bellé Diel ${ }^{1}$, Vanusa A. Casarin ${ }^{2}$, Marcelo P. Stracke ${ }^{1}$, Deoclécio J. C. da Silva ${ }^{3 *}$, \\ Antonio V. Dos Santos ${ }^{1}$, Renato Przyczynski ${ }^{4}$
}

${ }^{3 *}$ Corresponding author. Universidade Federal de Santa Maria/ Santa Maria - RS, Brasil.

E-mail: deocleciojunior2009@hotmail.com | ORCID: https://orcid.org/0000-0002-2395-2878

\section{KEYWORDS}

biodigesters, renewable energies, pig farming, economic management model.

\begin{abstract}
Faced with the increasing demand for renewable energy, researchers have developed several ways to generate them, such as biogas. Thus, the present study aims to demonstrate the economic viability of electricity generation from biodigesters in a pig farm to contribute to sustainable development by reducing pollution in the environment. Studies focused on biomass derived from pig waste are still scarce. Moreover, one of the motivations of the present study is the fact that Brazil is a major producer and exporter of pig meat, with most of the production taking place in the south and southeast regions. The methodology used is defined as exploratory, descriptive, explanatory, and applied. The scientific procedures were documentary and bibliographic research, case study, and cost analysis. An economic management model was developed using financial management instruments such as cash flow, internal rate of return, and simple and discounted payback, confirming the economic viability of the investment made for generating energy from animal biomass produced in a pig farm located in the interior of Rio Grande do Sul.
\end{abstract}

\section{INTRODUCTION}

In recent years, globally, much has been said about renewable energies and waste utilization in the production of electricity. However, only few studies addressed the resulting economic values and management of small investments in rural properties. Some studies that investigated production and waste, such as the report of the Brazilian Association of the Producing and Exporting Industry of Pig Meat (ABIPECS, 2016), showed that pig production decreased from 2.362.374 heads in 2007 to 2.100.301 heads in 2015. The domestic market represents $84.8 \%$ of the destination, while exports represent $15.2 \%$. The export indices of meat, cuts, offal, leather, and skin increased from 2.556 in 2000 to 3.643 thousand/ton in 2015 , which corresponds to an increase of $42.53 \%$. The southern region of the country accounts for $69.56 \%$ of the total exports. The State of Rio Grande do Sul occupies the third position at $20.69 \%$.

Brazil remains the third-largest producer and fourth-largest exporter of pig meat. This is due to its market potential, investments, and modernizations, which made it possible to maintain its growth. While there is increased competition, pressure on costs, and difficulties in accessing some markets, exports have maintained a good performance. Brazil exports 581.000 tons of meat to approximately 60 countries in several continents, such as Asia, America, and Africa.

The necessity of biodigesters arises from the need to properly allocate waste from pig farming and especially to ensure cost efficiency by utilizing waste, which, without the correct treatment, could cause pollution.

This study aims at investigating the use of renewable energy sources, especially the use of biogas as a source of renewable energy for electricity generation. Currently, the application of technologies that promote sustainable development is gaining prominence, leading to high-quality economic, industrial, and commercial relations.

A case study was conducted on a pig farm currently ranking fourth among companies that export meat and pig products. The property is located in the Northwest of the State of Rio Grande do Sul, in the municipality of Santo Cristo. At the moment, it has a single biodigester generating energy for five houses and for the maintenance of the farm, which today has a breeding stock of 1,480 dams and around 3,310 weaned piglets.

The purpose of the work is to disseminate the findings of this study to other farms throughout the country and other countries which engage in pig

${ }_{1}^{1}$ Universidade Regional Integrada do Alto Uruguai e das Missões - Campus Santo Ângelo/ Santo Ângelo - RS, Brasil.

${ }^{2}$ Faculdade Santo Ângelo/ Santo Ângelo - RS, Brasil.

${ }^{4}$ Instituto de Saúde Esportiva e Estética de Porto Alegre - ISEEC/ Porto Alegre- RS, Brasil. 
production, as the final product of this study will be a freeaccess web page. We started from the COREDE Fronteira Noroeste region, which is located in the State of Rio Grande do Sul, Brazil. Given the foregoing, the scientific motivation of this study is to conduct a case study with the data collected from a real and active property in the market and use these data to develop a management model that can be applied to similar studies in Brazil and other pigproducing countries. Thus, its main objective is to develop an economic management model that confirms the feasibility of the transformation of animal biomass into electricity. The cost resulting from the installation and maintenance of biodigesters will be presented, and the final product will be a free-access web page.

The theoretical framework used in the study, the authors who assisted the study, and the necessary theoretical apparatus are presented intially, followed by the methodology and the steps necessary for developing the scientific method and obtaining the results. Subsequently, the results and discussions on the development of the work and its importance for the field of study are presented, followed by conclusions.

\section{Theoretical framework}

The need for environment conservation and ensuring the well-being of the population have led the scientific community to dedicate more efforts in searching for alternatives to pollution waste treatment and for the means of transforming them into renewable energy sources. In this sense, the implementation of techniques aimed at minimizing environmental impact and rationalizing energy use by using biodigesters in rural areas should be highlighted, as they relate to the sanitation and energy conservation and stimulate the organic recycling of nutrients (Barbosa, 2003). It has been stated that promoting the use of biogas from such a production line is a promising option for achieving the goals established by 2030, particularly the universal access to energy (Ortiz et al., 2017). Given this, knowledge about this subject becomes fundamental, increasingly fostering the dissemination of sustainable thinking and sustainable alternatives.

\section{Sustainable Development}

This study considers the word sustainable as referring to a process of transformation and evolution, and that encompasses the whole society. Furtado (1980) mentions that the concept of development is used in two ways. The first is concerned with the evolution of a social system of production that becomes effective and raises productivity through the accumulation and progress of techniques. The second is concerned with the degree of satisfaction and human needs.

In the mid-twentieth century, the meaning of development expanded and began to encompass social characteristics such as improvements in education, health, sanitation, safety, and economic aspects (Furtado, 1968). Nevertheless, economic growth remains a necessary variable for development to occur, and it has been stated that the engagement of sustainable practices, the multiplier effect, and the increase in the number of people involved therein are extremely relevant for ensuring assertiveness in companies and promoting education focused on sustainable development (Souza, 1999; Kevany, 2007).

\section{Biodigesters in Brazil}

The Brazilian Company of Technical Assistance and Rural Extension (Empresa Brasileira de Tecnologia e Extensão Rural, EMBRATER) launched the project for the Diffusion of Biogas in the agricultural environment in 1977. They were willing to build seven thousand biodigesters by 1979 , but they only were able to build three thousand units. According to Barrera (2011), there was a lack of financial resources and technical training to operate the equipment. In 1981, a specific credit line was launched by the Central Bank of Brazil for the construction of biodigesters, but the program was decommissioned in December of the same year.

The project for the diffusion of biodigesters began its activities without the necessary support of applied research. The extensionists took on the responsibility of transferring a new technology based only on experiments conducted outside Brazil.

In addition to the lack of knowledge, another aggravating factor was the government policy at the time, which defined Brazil's energy options based on external events. Because the government could not establish regional policies with clearly scaled long-term plans and goals, it subsidized liquefied petroleum gas (LPG).

However, despite the difficulties and contradictions, the experiences lived by extensionists in the field allowed the country to gradually master the technologies for the use of biodigesters, thus decreasing the imports of LPG and fertilizers. Barrera (2011), states that the handling technique and the technology for constructing biodigesters was already available to the Brazilian industry, and that there exists a technological resource of goods, equipment, and engines that generate biogas.

Studies demonstrate that Brazil has a strong potential for energy generation using biodigesters, especially using waste from rural areas. Costa \& Guilhoto (2015) showed the impacts of the lack of sanitation in rural environments and indicated a great potential for income generation and employment resulting from the implementation of biodigester septic tanks.

Therefore, it has been stated that the use of renewable fuels, such as biofuels, is one of the strategic alternatives to modify the energy matrix of countries, and the use of biogas for electricity generation is likely to be increasingly fostered in Brazil (Pazuch, 2017). Given this, it can be said that the use of biogas is promising.

\section{Biogas}

Biogas is a gas mixture obtained from the decomposition of organic matter under anaerobic conditions; that is, it is produced from the degradation of organic matter by microorganisms and lack of air. The amount of biogas produced depends on the substrate used and favorable environmental conditions.

Generally speaking, although Brazil has great potential to stand out in the production of biogas as it emits a large amount of waste, financial investments in this area are still incipient. It is estimated that with the current stock of pigs, it would be possible to produce 4 million cubic meters of biogas per day. (Canal, 2016). Given this, it can be stated that biogas is a renewable source of energy that requires the involvement and awareness of all 
communities to ensure greater success in its implementation and utilization (Dinanti et al., 2017).

\section{Biogas in Brazil}

In the middle of 1990, the use of biogas gained momentum again, this time to prevent a new oil crisis, but especially because of environmental issues. At that time, developed and developing countries signed the Kyoto Protocol, where they committed to create alternatives to reduce the emission of gaseous pollutants such as methane and carbon dioxide (Karlsson, 2013).

According to the author, most of the biodigesters in Brazil are installed in rural areas, due to the large amount of waste produced mainly by indoor-reared animals, thus allowing the production of biofertilizers and biogas. This has contributed to the generation of renewable energy and, consequently, to the reduction of environmental pollution and energy use (Rajendran et al., 2012).

An example of an environmental problem arising from the production of indoor-reared pigs is the pig farming in the rural area of the State of Santa Catarina, especially in the western region. Many of the pig herds are close to water flows, and, unfortunately, the manure produced by them ends up polluting rivers and groundwater (Reis, 2012).

In the case of Brazil, it is possible to say that giving a correct destination for the produced waste and information on basic sanitation are paramount attitudes for ensuring a harmonious interaction between society and the environment. For Reis (2012), efficient sewage collection and proper treatment are crucial for sustainability. Urban environments not only suffer from a lack of infrastructure but also from a lack of resources for waste disposal.

In some countries, especially India, the use of plant and animal biomass for energy generation in poorer regions is quite common. An integrated resource management would be of great value for sustainable development, as it would promote reduction, reuse, and recycling, which are indispensable for those who want to progress with sustainability and environmental awareness.

Similarly, Trigueiro (2005) mentions the implantation of biodigesters and the curiosity raised by their use as a resource to convert animal sewage into energy. For every kilogram of organic matter that enters the process of biodigestion, only fifty grams remain as waste. External chemicals are not added in this model of sewage treatment, and just the natural process of degradation is facilitated. Importantly, the gas generated in the process can be used as a source of energy.

According to the author, one of the most important functions of the earth is filtering rainwater; but when cities are built, especially with an asphalt blanket, water cannot flow naturally. When talking about sustainable development and water resources, one must think that although the improvement of streets and roads are important, river galleries, where water can flow freely and follow its course, should be installed in the city.

In the municipality of Curitiba, in the State of Paraná, a law was created which aims at instituting measures that induce the conservation and rational use of water. Law 10,785 was created in 2003 and refers to the rational use of water resources and the use of alternative sources for water abstraction in new buildings, including the implementation of water consumption awareness programs.
If the construction does not comply with the requirements established by law, the municipality denies the permit.

The Carta da Terra (Earth Letter) mentions that the well-being of humanity depends exclusively on the preservation of a healthy biosphere, with all ecological systems in harmony. As ecological resources are finite, the preservation, protection, vitality, and beauty of the earth depend exclusively on the actions of human beings.

Considering this scenario, the Kyoto Protocol was established in Japan in 1997 and came into force in February 2005. This protocol is aimed at the stabilization of greenhouse gas (GHG) emissions. It should be emphasized that agricultural farms, in particular pig farms, are major emitters of gaseous pollutants.

According to Welzer (2010), targets formulated based on the Kyoto Protocol are aimed at reducing GHG emissions through the implementation of a new system. However, it is difficult to contain the destruction of land, given the disorderly urban growth, the increase in the individual road fleet, and the unbridled growth of industries, which cause a constant increase in the emission of gaseous pollutants.

In Brazil, there are no reliable statistics regarding the potential of biogas. It can be said that solutions for the use of rural gas pipelines, which can be built in the flexible piping of polyethylene from 20 to 90 centimeters to reduce losses and strength of the load, would be of paramount importance for gas transport.

\section{Economic Feasibility}

According to Marquezan \& Brondani (2006), in order to develop an appropriate economic project, it is necessary to determine its economic viability. The analysis of economic viability enables the visualization, through projections and numbers, of the potential return on investment. It is necessary to estimate all expenses arising from the initial investment, operation, and maintenance of revenues generated over a given period to prepare the cash flow of these investments, revenues, expenses, and costs, thus determining the indicators for the success of the enterprise.

The general objective of the analysis of economic viability, according to the Brazilian Service of Support for Micro and Small Enterprises (Serviço Brasileiro de Apoio às Micro e Pequenas Empresas, SEBRAE, 2016), is to assist an entrepreneur in evaluating an investment plan by showing whether a given project is viable or not.

\section{MATHERIAL AND METHODS}

According to Vergara (2014), the study was classified as ex post facto, as the variables that occur throughout the process cannot be changed, that is, they have already occurred. This was a field research as the relevant data were collected from a farm where a biodigester was installed. This was a documentary and bibliographic research because information were collected from documents, records, annals, and balances. It was based on publications in books, magazines, journals, and the Qualis Capes score of articles and works involving biodigesters, all investigating the State of Rio Grande do Sul.

The research was quantitative and descriptive because the analysis of economic viability was based on cost data and economic calculations. The research was applied in nature, as it is closely linked to the increase of 
knowledge and development of new processes and products to meet the need of the Região das Missões.

It was based on a case study in a farm aggregated to the Fridge Alibem, which already produces biogas and where biodigesters already generate electricity. After surveying the values invested in infrastructure, sheds, collector tanks, and the installed engine, the costs were calculated. Cash flow, payback, and present value were calculated based on the literature review.

\section{RESULTS AND DISCUSSION}

Real information and classical and current works were used in the development of this work, with a detailed investigation of the instruments and mechanisms of the biodigesters used in the pig farm and the impact caused by the use of this renewable energy system.

With regard to finance, authors such as Hes et al. (2017) assert the importance of knowing investments and microcredit. They depict the related reality in Sri Lanka, dispelling the existing doubts about the potential of commercial microcredit as a strategic vehicle for the implementation of small-scale biogas plants. Unlike their study, the present study shows the economic viability of using biogas as a source of electrical energy from a pig farm, complementing the former study.

According to the information collected from the farm, a biodigester with a capacity of 680.000 liters of manure (a mixture of water and manure waste) per month, costs $\mathrm{R} \$ 41.850,00$, which is the value corresponding to the first engine purchased. The investment made to achieve a greater production was $\mathrm{R} \$ 168.500,00$, corresponding to an engine of approximately 65 kilovolt-amperes, considering the initial investment, reform, and exchange. Table 1 shows the items that make up the biodigester.

TABLE 1. Items comprising the biodigester.

\begin{tabular}{cc}
\hline Items & Values in R\$ \\
\hline Biodigester GGB 65 & $140.000,00$ \\
Stainless steel mixer & $14.000,00$ \\
Gas Cooler & $12.000,00$ \\
Air-injecting compressor & $1.500,00$ \\
Belt/Water Pump & $1.000,00$ \\
\hline Initial Investment & $\mathbf{1 6 8 . 5 0 0 , 0 0}$ \\
\hline
\end{tabular}

Source: Prepared by the authors.

In the following, the financial projections of the next ten years of investment for electricity generation using biogas from the biodigester installed in the property are presented. The analysis was performed considering the following indicators: cash flow, net present value (NPV), internal rate of return (IRR), and simple and discounted payback.

The initial investment of the project was $\mathrm{R} \$$ 168.500,00, as shown in Table 1, considering the biodigester, mixer, cooler, and other equipment. The share capital of this investment consists of $83 \%$ of third-party resources and $17 \%$ of own resources.

The projected cash flow is shown in Table 2.

TABLE 2. Projected cash flow for years 0 to 5 .

\begin{tabular}{|c|c|c|c|c|c|c|}
\hline Macroeconomic Data & Year 0 & Year 1 & Year 2 & Year 3 & Year 4 & Year 5 \\
\hline Inflation (CPI)\% & $9,5 \%$ & $9,5 \%$ & $9,5 \%$ & $9,5 \%$ & $9,5 \%$ & $9,5 \%$ \\
\hline Income Statement & Year 0 & Year 1 & Year 2 & Year 3 & Year 4 & Year 5 \\
\hline Operating Revenue & - & $78.000,00$ & $85.410,00$ & 93.523,95 & $102.408,73$ & 112.137,55 \\
\hline$(+)$ Electricity revenue & - & $78.000,00$ & $85.410,00$ & $93.523,95$ & $102.408,73$ & $112.137,55$ \\
\hline Operating Cost & - & $32.221,00$ & $34.054,12$ & $36.061,39$ & $38.259,34$ & $40.666,11$ \\
\hline $\begin{array}{l}\text { (-) Fixed costs with } \\
\text { Biodigester }\end{array}$ & - & $8.496,00$ & $9.303,12$ & $10.186,92$ & $11.154,67$ & $12.214,37$ \\
\hline (-) Variable costs & - & $10.800,00$ & $11.826,00$ & $12.949,47$ & $14.179,67$ & $15.526,74$ \\
\hline (-) Interest on financing & - & $4.500,00$ & $4.500,00$ & $4.500,00$ & $4.500,00$ & $4.500,00$ \\
\hline (-) Depreciation & - & $8.425,00$ & $8.425,00$ & $8.425,00$ & $8.425,00$ & $8.425,00$ \\
\hline Gross Profit & - & $45.779,00$ & $\mathbf{5 1 . 3 5 5 , 8 8}$ & $57.462,56$ & $64.149,38$ & $71.471,45$ \\
\hline Net Income & - & $45.779,00$ & $\mathbf{5 1 . 3 5 5 , 8 8}$ & $57.462,56$ & $64.149,38$ & $71.471,45$ \\
\hline$(+)$ Depreciation & - & $8.425,00$ & $8.425,00$ & $8.425,00$ & $8.425,00$ & $8.425,00$ \\
\hline (=) Availability & - & $45.779,00$ & $\mathbf{5 1 . 3 5 5 , 8 8}$ & $57.462,56$ & $64.149,38$ & $71.471,45$ \\
\hline$(+)$ Own Fundraising & $28.500,00$ & - & - & - & - & - \\
\hline $\begin{array}{l}\text { (+) Third-Party } \\
\text { Fundraising }\end{array}$ & $140.000,00$ & - & - & - & - & - \\
\hline $\begin{array}{l}\text { (-) Return of Third-Party } \\
\text { Resources }\end{array}$ & - & $17.500,00$ & $17.500,00$ & $17.500,00$ & $17.500,00$ & $17.500,00$ \\
\hline$(=)$ Enterprise Cash Flow & - & $28.279,00$ & $33.855,88$ & $39.962,56$ & $46.649,38$ & $53.971,45$ \\
\hline $\begin{array}{l}(=) \text { Accumulated } \\
\text { Resources }\end{array}$ & $168.500,00$ & $28.279,00$ & $62.134,88$ & $102.097,44$ & $148.746,83$ & $202.718,27$ \\
\hline
\end{tabular}

Source: Prepared by the authors. 
In Table 2, we can observe the synthesis of the data referring to the first five years of investment. An indexer of $9.5 \%$ per annum based on the consumer price index (CPI) was used for the calculation. In the first five years, the cash flow became positive; that is, from the fourth to the fifth year, the cost of the biodigester would already be covered. Table 3 shows the calculation until the tenth year.

TABLE 3. Projected cash flow for years 6 to 10 .

\begin{tabular}{lccccc}
\hline Macroeconomic Data & Year 6 & Year 7 & Year 8 & Year 9 & Year 10 \\
\hline Inflation (CPI) $\%$ & $9,5 \%$ & $9,5 \%$ & $9,5 \%$ & $9,5 \%$ & $9,5 \%$ \\
\hline Income Statement & Year 6 & Year 7 & \multicolumn{1}{c}{ Year 8 } & Year 9 & Year 10 \\
\hline Operating Revenue & $\mathbf{1 2 2 . 7 9 0 , 6 2}$ & $\mathbf{1 3 4 . 4 5 5 , 7 3}$ & $\mathbf{1 4 7 . 2 2 9 , 0 3}$ & $\mathbf{1 6 1 . 2 1 5 , 7 8}$ & $\mathbf{1 7 6 . 5 3 1 , 2 8}$ \\
\hline (+) Electricity revenue & $122.790,62$ & $134.455,73$ & $147.229,03$ & $161.215,78$ & $176.531,28$ \\
\hline Operating Cost & $\mathbf{4 3 . 3 0 1 , 5 1}$ & $\mathbf{4 6 . 1 8 7 , 2 8}$ & $\mathbf{4 9 . 3 4 7 , 2 0}$ & $\mathbf{4 8 . 3 0 7 , 3 0}$ & $\mathbf{5 2 . 0 9 6 , 1 2}$ \\
\hline (-) Fixed costs with Biodigester & $13.374,73$ & $14.645,33$ & $16.036,64$ & $17.560,12$ & $19.228,33$ \\
\hline (-) Variable costs & $17.001,78$ & $18.616,95$ & $20.385,56$ & $22.322,19$ & $24.442,79$ \\
\hline (-) Interest on financing & $4.500,00$ & $4.500,00$ & $4.500,00$ & 0 & 0 \\
\hline (-) Depreciation & $8.425,00$ & $8.425,00$ & $8.425,00$ & $8.425,00$ & $8.425,00$ \\
\hline Gross Profit & $\mathbf{7 9 . 4 8 9 , 1 1}$ & $\mathbf{8 8 . 2 6 8 , 4 5}$ & $\mathbf{9 7 . 8 8 1 , 8 3}$ & $\mathbf{1 1 2 . 9 0 8 , 4 8}$ & $\mathbf{1 2 4 . 4 3 5 , 1 6}$ \\
\hline Net Income & $\mathbf{7 9 . 4 8 9 , 1 1}$ & $\mathbf{8 8 . 2 6 8 , 4 5}$ & $\mathbf{9 7 . 8 8 1 , 8 3}$ & $\mathbf{1 1 2 . 9 0 8 , 4 8}$ & $\mathbf{1 2 4 . 4 3 5 , 1 6}$ \\
\hline (+) Depreciation & $8.425,00$ & $8.425,00$ & $8.425,00$ & $8.425,00$ & $8.425,00$ \\
\hline (=) Availability & $\mathbf{7 9 . 4 8 9 , 1 1}$ & $\mathbf{8 8 . 2 6 8 , 4 5}$ & $\mathbf{9 7 . 8 8 1 , 8 3}$ & $\mathbf{1 1 2 . 9 0 8 , 4 8}$ & $\mathbf{1 2 4 . 4 3 5 , 1 6}$ \\
\hline (-) Return of Third-Party Resources & $17.500,00$ & $17.500,00$ & $17.500,00$ & - & - \\
\hline (=) Enterprise Cash Flow & $61.989,11$ & $70.768,45$ & $80.381,83$ & $112.908,48$ & $124.435,16$ \\
\hline (=) Accumulated Resources & $264.707,39$ & $335.475,84$ & $415.857,67$ & $528.766,14$ & $653.201,30$ \\
\hline Sour & & & &
\end{tabular}

Source: Prepared by the authors.

The same parameters were used from the sixth to the tenth year. It is noteworthy that from the eighth year onwards, there is no more return of third-party resources. Based on the cash flow statements with projections for the next fifteen years, it is possible to obtain the financial and economic indices of the results of this implementation.

According to Pereira (2009), the calculation of net present value (NPV) allows the conversion of the value of money to the present time, which in this case results in $\mathrm{R} \$$ 117.247,41. This method considers the interest rate for the period, comparing the cash inflows and outflows on the project start date, discounting future cash flow returns with the minimum attractive rate of return (MARR).
The IRR was $26 \%$, confirming that the implantation of the biodigester is feasible in a medium-sized farm such as the one considered in this study. However, if the IRR was below $14.05 \%$, the project would be unfeasible.

Simple payback was calculated based on the investment made versus the profit earned in the first year, which was determined to be in 5.96 years. However, this formula does not provide for correction over time.

In discounted payback, the values are converted into the present value, verifying with greater accuracy the actual time for the return of investment. Thus, it is based on the cash flow, as shown in Table 4.

TABLE 4. Discounted payback for years 0 to 5 .

\begin{tabular}{lcccccc}
\hline Period (n) & 0 & 1 & 2 & 3 & 4 & 5 \\
\hline Initial Investment & Year 0 & Year 1 & Year 2 & Year 3 & Year 4 & Year 5 \\
\hline Expected Annual Revenue & $168.500,00$ & & & & & \\
\hline Expected Annual Expenditure & & $78.000,00$ & $85.410,00$ & $93.523,95$ & $102.408,73$ & $112.137,55$ \\
\hline Nominal Profit (NP) & & $49.721,00$ & $51.554,12$ & $53.561,39$ & $55.759,34$ & $58.166,11$ \\
\hline Present Value (PV) & & $\mathbf{2 8 . 2 7 9 , 0 0}$ & $\mathbf{3 3 . 8 5 5 , 8 8}$ & $\mathbf{3 9 . 9 6 2 , 5 6}$ & $\mathbf{4 6 . 6 4 9 , 3 8}$ & $\mathbf{5 3 . 9 7 1 , 4 5}$ \\
\hline Investment Balance & $\mathbf{- 1 6 8 . 5 0 0 , 0 0}$ & $\mathbf{- 1 4 3 . 7 0 4 , 7 3}$ & $\mathbf{- 1 1 7 . 6 7 6 , 5 7}$ & $\mathbf{- 9 0 . 7 3 8 . 4 4}$ & $\mathbf{- 6 3 . 1 6 6 , 6 6}$ & $\mathbf{- 3 5 . 1 9 6 , 9 8}$ \\
\hline
\end{tabular}

Source: Authors. 
Contrary to what was observed in Table 2, where the values are included in the discounted payback, in Table 4, there is still no return on investment in the fifth year.

In table 5, the return on investment was observed from the sixth to the seventh year.

TABLE 5. Discounted Payback for years 6 to 10.

\begin{tabular}{lccccc}
\hline Period (n) & 6 & 7 & 8 & 9 & 10 \\
\hline Initial Investment & Year 6 & Year 7 & Year 8 & Year 9 & Year 10 \\
\hline Expected Annual Revenue & & & & & \\
\hline Expected Annual Expenditure & $122.790,62$ & $134.455,73$ & $147.229,03$ & $161.215,78$ & $176.531,28$ \\
\hline Nominal Profit (NP) & $60.801,51$ & $63.687,28$ & $66.847,20$ & $48.307,30$ & $52.096,12$ \\
\hline Present Value (PV) & $\mathbf{6 1 . 9 8 9 , 1 1}$ & $\mathbf{7 0 . 7 6 8 , 4 5}$ & $\mathbf{8 0 . 3 8 1 , 8 3}$ & $\mathbf{1 1 2 . 9 0 8 , 4 8}$ & $\mathbf{1 2 4 . 4 3 5 , 1 6}$ \\
\hline Investment Balance & $28.167,20$ & $28.195,04$ & $28.079,90$ & $34.583,50$ & $33.418,75$ \\
\hline
\end{tabular}

Source: Authors.

Based on the discounted payback, in which all the profits of the period are converted into present value (PV), the farm would take 6,249326 years, precisely 6 years and 3 months, to obtain a positive NPV for the investment of $\mathrm{R} \$ 168.500,00$.

The calculations showed an IRR of $26 \%$. This number corroborates the NPV, which points to a positive balance at the end of the analysis period, showing that it has a rate of return above the MARR.

Based on the results obtained, it is possible to state that the rate of return of $26 \%$ combined with an NPV higher than the investment confirms the economic and financial viability of the investment. The 6-year term is compatible with the investment in electricity generation. However, the information has a framework in which the economic feasibility depends on factors such as the purchase of new equipment, maintenance, and climate, which directly influence the ability of the enterprise being sustainable.

Currently, the farm does not store the additional energy generated, thus it would be interesting to market the surplus produced to an energy-generating cooperative or even to other pig producers in the region. Producer cooperatives in the State of Paraná generate energy from biogas and sell the surplus to the local concessionaire, which pays for the energy at the value stipulated by the Agência Nacional de Energia Elétrica (National Agency of Electrical Energy). Therefore, it would constitute an additional revenue.

On the other hand, it is necessary to analyze the budget of investments made and the annual cost because the variable costs in this study were higher when compared to other cases in the literature; thus the higher contribution of investments, which directly influenced the investment analysis.

The use of third-party capital, in this case, is extremely viable and beneficial, as the government provides specific credit lines for investments in renewable energy and for the promotion of small and medium-sized producers for whom they provide differentiated, accessible, and facilitated interest rates and payment methods.

The analyzed farm used PRONAMP, whose interest rate is $7.75 \%$ per annum, corresponding to almost half of RT. Government policy provides for significant subsidies in the renewable energy sector, mainly for energy generation. Among the institutions that promote these technologies is the Banco Nacional do Desenvolvimento Econômico e Social (National Bank for Economic and Social Development), which offers credit lines of up to $9.5 \%$ per annum, with a limit of $80 \%$ of the capital required for venturing.

Another issue to be analyzed besides the technical aspects is the amount of biogas produced, because it is directly linked to the number of pigs. When it comes to energy production, the farm in this study is classified as large, with an expressive production of biogas. Because it works with more than 1.300 dams and has more than 4.000 piglets in the nursery, it has no difficulty in reaching the minimum amount of waste needed for generating biogas. According to Lindemeyer (2008), properties with less than 500 pigs have a great difficulty in achieving adequate levels of biogas generation.

Therefore, the farm has a great potential to serve as a basis for other producers, and its management techniques can serve as an example for other farms to use the biomass generated from reusable waste. In other words, it serves as a model farm, providing options that can bring economic and environmental benefits.

\section{CONCLUSIONS}

A literature review on pig farming and renewable energy was performed in the search for energy alternatives for local and regional development and for the creation of an economic management model. Concepts about renewable energy, biogas, investigation of the basic characteristics of biogas generation, and what it represents in terms of local and regional development were presented.

Data collection and technical visits allowed for the verification of the budget and the investment made for the installation of the biodigester. Subsequently, the economic and financial return of the facility was assessed, concluding that it was economically viable.

Based on the economic data obtained, it was found that using biogas as a source of electrical energy from a pig farm is viable. However, such process still faces obstacles such as regulatory instability and lack of structural and financial support to pig farmers. In this regard, one must also consider the environmental issue which is greatly benefited from the use of renewable energies. 
The technical and operational feasibility of using biogas for power generation was confirmed. Issues that were previously considered as obstacles to the adoption of alternative energies, especially those related to biogas, were overcome due to the advancement of microgeneration and distribution technologies. However, economic viability still raises concerns, which led to the development of this study.

\section{REFERENCES}

ABIPECS - Associação Brasileira da Indústria Produtora e Exportadora de Carne Suína (2016) Relatório. Available: http://www.ebc.com.br/abipecs. Accessed: Jan 31, 2017.

Barrera P (2011) Biodigestores: energia, fertilidade e saneamento para a zona rural. São Paulo, Ícone.106 p.

Barbosa JMN (2003) Estudo do comportamento da DBO em suporte aeróbio de oxigênio puro. Coeficientes cinéticos e fatures de correlação. Dissertação Mestrado em Saúde Pública, Rio de Janeiro, Fiocruz.

Canal - Jornal da Bioenergia (2016) O potencial da produção de biogás. Available:

http://www.canalbioenergia.com.br/opcoes-de-materiaspara-producao-de-biogas/. Accessed: Oct 27, 2016.

Carta da Terra. Available:

http://www.mma.gov.br/responsabilidade-

socioambiental/agenda-21/carta-da-terra,

http://www.mma.gov.br/estruturas/agenda21/_arquivos/Ca rtaDaTerraHistoria2105.pdf>. Accessed: Jun 26, 2017.

Costa CC da, Guilhoto JJM (2015) Saneamento rural no Brasil: impacto da fossa séptica biodigestora. Engenharia Sanitária e Ambiental 1(1).

Dinanti D, Erlina DF, Meidiana C (2017) The readiness of farmer communities in biogas development (A case study: Wiyurejo Village, Malang Regency Indonesia). IOP Conference Series: Earth and Environmental Science 70(1):012036

Furtado C (1980) Pequena introdução ao desenvolvimento: enfoque interdisciplinar. São Paulo, Nacional.

Furtado C (1968) Teoria e Políticado Desenvolvimento Econômico. São Paulo, Nacional.

Hes T, Mintah S, Sulaiman H, Arifeen T, Drbohlav P, Salman A (2017) Potential of microcredit as a source of finance for development of Sri Lankan biogas industry. Energy \& Environment 28(5-6):608-620.
Karlsson T (2013) Manual básico de biogás. Available: https://www.univates.br/editoraunivates/media/publicacoes/71/pdf_71.pdf. Accessed: Mar 22, 2015.

Kevany KD (2007) Building the requisite capacity for stewardship and sustainable development. International Journal of Sustainability in Higher Education 8(2):107-122.

Lindemeyer RM (2008) Análise da viabilidade econômicofinanceira do uso do biogás como fonte de energia elétrica. Monografia, Santa Catarina, Universidade Federal de Santa Catarina, 103p.

Marquezan LHF, Brondani G (2006) Análise de investimentos. Revista Eletrônica de Contabilidade 3(1):35.

Ortiz W, Terrapon-Pfaff J, Dienst C (2017) Understanding the diffusion of domestic biogas technologies. Systematic conceptualisation of existing evidence from developing and emerging countries. Renewable and Sustainable Energy Reviews 74:1287-1299.

Pazuch FA, Siqueira J, Friedrich L, Lenz AM, Nogueira CEC, Souza SNM (2017) Co-digestion of crude glycerin associated with cattle manure in biogas production in the State of Paraná, Brazil. Acta Scientiarum. Technology $39(2)$.

Pereira G (2009) Viabilidade Econômica da Instalação de um biodigestor em propriedades rurais. Available: http://bibliodigital.unijui.edu.br:8080/xmlui/bitstream/han dle/123456789/214/Disserta\%C3\%A7\%C3\%A3o\%20Gilb erto\%20Pereira.pdf? sequence $=1$. Accessed: Nov 30, 2015.

Rajendran K, Aslanzadeh S, Taherzadeh MJ (2012) Household biogas digesters: a review. Energies 5(8):2911-2942.

Reis LB dos (2012) Energia, recursos naturais e a prática do desenvolvimento sustentável. Barueri, SP, Manole.

Souza, NJ. (1999). Desenvolvimento Econômico. $4^{\text {a }}$ ed.São Paulo: Atlas.

Trigueiro A (2005) Mundo sustentável: abrindo espaço na mídia para um planeta em transformação. São Paulo, Globo.

Vergara SC (2014) Projetos e relatórios de pesquisa em administração. São Paulo, Atlas, 15 ed.

Welzer H (2010) Guerras Climáticas: Por que mataremos e seremos mortos no século 21. São Paulo, Geração Editorial. 